\title{
The Role Of Collaborative Scholarship In The Mentorship Of Doctoral Students
}

Genevieve Pinto Zipp, Seton Hall University, USA

Terrance Cahill, Seton Hall University, USA

MaryAnn Clark, Seton Hall University, USA

\begin{abstract}
The work of a professor is the "scholarship of teaching" (Boyer, 1990). The strength of the teaching and learning environment is fostered by a dynamic interplay between the mentor (scholar) and the mentee (student). Boyer (1990) suggests that in order to be a scholar, one must have "a recognition that knowledge is acquired through research, through synthesis, through practice, and through teaching." However, as the academy has placed increased emphasis on research productivity as a concrete measure of scholarship, faculty may lose sight of what it means to view teaching as a scholarship. For example, if mentorship collaborations (studentffaculty, faculty/faculty) are not viewed as scholarship activities, faculty may limit the amount or depth of student mentorship or peer collaborations to pursue their own research endeavors and thereby compromise the scholarship of teaching. Research is needed to gain an understanding of how faculties view collaborative research in relation to the scholarship of teaching. The purpose of this paper is to first briefly describe the student-centered mentorship model for doctoral students proposed by Zipp and Olson (2008); second, to address the question, "Should the outcomes associated with this model be recognized as faculty scholarship?"; and third, to present pilot data of faculty perceptions on the role of collaborative scholarship in the mentorship of doctoral students.
\end{abstract}

Keywords: collaborative scholarship outcomes, doctoral student mentorship functions, faculty perceptions on scholarship

\section{INTRODUCTION}

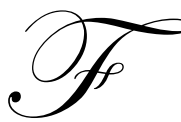

aculty roles within an academic institution traditionally include teaching, scholarship and service. Student mentorship is imbedded within each of these roles to varying degrees, dependent upon the academic degree sought by the student and the curricular design of the program. In doctoral education, understanding the importance of this mentorship (apprenticeship) role can lead to the enhancement of the doctoral program and the productivity of the students and faculty. In doctoral education, the student-centered mentorship model of learning is recognized as foundational to the development of students. The student-centered mentorship model of learning is foundational in assisting doctoral students to recognize that the doctoral experience is a "journey" and not a means to an "end". This student-centered mentorship model, by definition, requires faculty to invest considerable time and effort working individually with students. While it is generally accepted that student mentoring is part of a faculty members' teaching responsibility, is it possible that this view is too limited when it comes to faculty in doctoral education? At the core of the doctoral student-centered mentorship model of learning is the focus on research for the production of new knowledge. In this context, research serves a teaching purpose, but the products of that research, both presentations and publications, serve a scholarship purpose. The question is, "Whose scholarship purpose is served by the products resulting from the student-centered mentorship model used in doctoral education?" It is common for universities and colleges to view this type of scholarship in different ways. Institutions may view these research activities as faculty scholarship, student scholarship, or simply as products of faculty teaching responsibilities. We propose a fourth option which reflects the tenets of the student-centered mentorship model of learning used in doctoral education - collaborative scholarship. With regard to scholarly products, the notion of collaborative scholarship accounts for the contributions of both the faculty and student in the 
student-centered mentorship model. The purpose of this paper is first to briefly describe the student-centered mentorship model for doctoral students; second, to address the question, "Should the outcomes associated with this model be recognized as faculty scholarship?" ; and third, to present pilot data of faculty perceptions on the role of collaborative scholarship in the mentorship of doctoral students.

The student-centered mentorship model of learning used in the Graduate Programs in Health Sciences is based upon the andragogy philosophical perspective on how adults learn. Andragogy is the art and science of teaching adults (Forrest \& Peterson, 2006) to develop as independent thinkers through actively engaging students. The andragogy philosophical perspective supports the use of problem-centered active learning strategies. It respects that learners bring resources to the learning environment and that their desire to learn or need to know develops from within themselves. Thus, adult learners are ready to learn, they are self directed, they use prior experiences, and they use a performance centered/problem-oriented approach to learn.

The "Layered Learning Mentorship Model (LLMM)" present in the PhD in Heath Sciences curriculum was designed to bridge the gap between why we teach and how we teach. The LLMM was founded on the philosophical orientation of cognitive processing-reasoning, which focuses on teaching students to develop and refine their intellectual processes. This approach is further complimented by Bloom's Six Levels of the Cognitive Domain. The overall emphasize of the model is on the "how" to learn not the "what" to learn. Three layers are incorporated into the LLMM. The first layer encompasses the Program's global areas of study such as core courses, research courses, practicum and electives. The second layer encompasses the content specialization areas of study in either Health Professions Leadership, Movement Science or Speech Language Pathology. Finally, the third layer encompasses the dissertation process activities. Threaded across the three layers of the LLMM is the research forum series. The series provides a forum for students at all levels to discuss their research ideas, methods, and findings amongst colleagues and the program faculty. Students participate initially as a critical audience and then as active presenters.

Core to student-centered LLMM is faculty mentorship provided to each student in the areas of teaching, scholarship and service. As a byproduct of this mentorship, collaborative-directed research products are produced. It is these collaborative-directed research projects in doctoral programs that stimulate the debate "whose scholarship purpose is served by the products resulting from the student-centered LLMM utilized in doctoral education?"

As Boyer (1990) argued, scholarship encompasses four interconnected dimensions: discovery, integration, application and teaching. Thus, scholarship is not limited to research alone. Doctoral faculties provide mentorship along these four dimensions to students so that they can develop and flourish as scholars. Collaborative research products are the outgrowth of these mentorship experiences. While we do not have one clearly accepted definition of collaboration, Austin and Baldwin (1991) described collaboration "as a cooperative endeavor". The endeavor encompasses coordinated efforts toward common goals. Thus, collaborators share responsibility and credit for the outcomes or products of these endeavors.

To explore university faculty perceptions of the role of collaboration in scholarship activities, a survey research project was utilized. The project research questions included:

1. How does university faculty view collaboration in their scholarship activities?

2. When students are involved in collaborative scholarship, how does faculty view the students' roles?

\section{METHODS}

\section{Subjects}

A sample of convenience - 100 full-time Seton Hall University faculty - voluntarily participated in completing an on-line university survey tool, asset, during the spring 2009 semester. 


\section{Procedures}

During the spring 2009 semester, all full-time faculty of the university were invited via a broadcast email to voluntarily complete an anonymous on-line survey assessing their perception of the role of collaboration in scholarship activities. While this survey has not been validated, it was reviewed by three senior faculty to determine its content appropriateness and clarity.

\section{Study Design}

A quantitative exploratory survey design was used to address the research questions. The dependent variables were the survey responses regarding perceptions and the independent variable was faculty demographics. Survey data analysis included the generation of percent agreement scores.

\section{RESULTS}

The subject pool was limited to 100 full-time faculty. Figure 1 suggests that $70 \%$ of those faculty members completing the survey taught graduate students and mentored student projects. It should be noted that in our university that the majority of faculty are not designated as graduate or undergraduate faculty as they are frequently called upon to provide instruction and mentorship at both academic levels. Only two schools within the university have faculty that only teach graduate students.

Tables 1 to 3 demonstrate percent agreement using a 5-point Likert scale of student's perceptions on several questions regarding faculty perceptions on collaborations and mentorship. Overall, the faculty supported two important ideas: 1) that the student research products depend on faculty mentorship and collaboration and 2) that collaborative student research products between student and faculty should account for faculty and student scholarship activities.

Figure 1

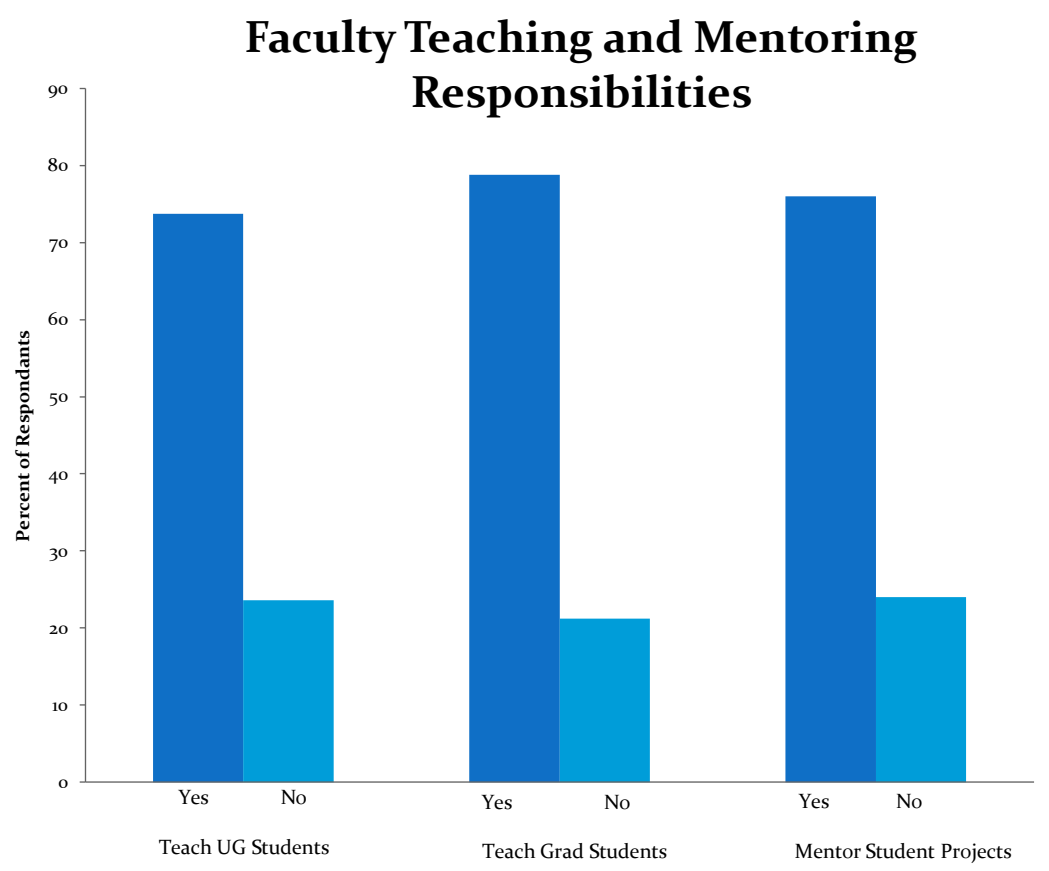




\section{Table 1. Faculty Perceptions of Scholarship}

\begin{tabular}{|c|c|c|c|c|c|}
\hline & $\begin{array}{l}\text { Strongly } \\
\text { Agree }\end{array}$ & Agree & Unsure & Disagree & $\begin{array}{l}\text { Strongly } \\
\text { Disagree }\end{array}$ \\
\hline \multicolumn{6}{|l|}{ Question 1} \\
\hline $\begin{array}{l}\text { I view } \\
\text { research as } \\
\text { scholarship }\end{array}$ & $\begin{array}{l}86.9 \% \\
(n=86)\end{array}$ & $\begin{array}{l}11.1 \% \\
(n=11)\end{array}$ & $\begin{array}{l}1.0 \% \\
(n=1)\end{array}$ & $\begin{array}{l}0 \% \\
(n=1)\end{array}$ & $\begin{array}{l}0 \% \\
(n=0)\end{array}$ \\
\hline \multicolumn{6}{|l|}{ Question 3} \\
\hline $\begin{array}{l}\text { I view } \\
\text { teaching as } \\
\text { scholarship. }\end{array}$ & $\begin{array}{l}37.1 \\
(n=36)\end{array}$ & $\begin{array}{l}24.7 \% \\
(n=24)\end{array}$ & $\begin{array}{l}3.4 \% \\
(n=13)\end{array}$ & $\begin{array}{l}7.5 \% \\
(n=17)\end{array}$ & $\begin{array}{l}7.2 \% \\
(n=7) b\end{array}$ \\
\hline \multicolumn{6}{|l|}{ Question 5} \\
\hline $\begin{array}{l}\text { I view service } \\
\text { as scholarship }\end{array}$ & $\begin{array}{l}15.3 \% \\
(n=15)\end{array}$ & $\begin{array}{l}18.4 \% \\
(n=18)\end{array}$ & $\begin{array}{l}19.4 \% \\
(n=19)\end{array}$ & $\begin{array}{l}25.5 \% \\
(n=25)\end{array}$ & $\begin{array}{l}21.4 \% \\
(n=21)\end{array}$ \\
\hline \multicolumn{6}{|l|}{ Question 7} \\
\hline $\begin{array}{l}\text { Faculty } \\
\text { scholarship } \\
\text { includes } \\
\text { collaboration }\end{array}$ & $\begin{array}{l}46.4 \% \\
(n=45)\end{array}$ & $\begin{array}{l}38.1 \% \\
(n=37)\end{array}$ & $\begin{array}{l}11.3 \% \\
(n=11)\end{array}$ & $\begin{array}{l}4.1 \% \\
(n=4)\end{array}$ & $\begin{array}{l}0 \% \\
(n=0)\end{array}$ \\
\hline
\end{tabular}

\section{Table 1 (cont'd). Faculty Perceptions of Scholarship}

\begin{tabular}{|c|c|c|c|c|c|}
\hline & $\begin{array}{l}\text { Strongly } \\
\text { Agree }\end{array}$ & Agree & Unsure & Disagree & $\begin{array}{l}\text { Strongly } \\
\text { Disagree }\end{array}$ \\
\hline \multicolumn{6}{|l|}{ Question 2} \\
\hline $\begin{array}{l}\text { My univ views } \\
\text { research as } \\
\text { scholarship }\end{array}$ & $\begin{array}{l}62.2 \% \\
(n=62)\end{array}$ & $\begin{array}{l}23.2 \% \\
(n=23)\end{array}$ & $\begin{array}{l}4.1 \% \\
(n=7)\end{array}$ & $\begin{array}{l}5.1 \% \\
(n=5)\end{array}$ & $\begin{array}{l}2.0 \% \\
(n=2)\end{array}$ \\
\hline \multicolumn{6}{|l|}{ Question 4} \\
\hline $\begin{array}{l}\text { My univ views } \\
\text { teaching as } \\
\text { scholarship }\end{array}$ & $\begin{array}{l}9.2 \% \\
(n=9)\end{array}$ & $\begin{array}{l}19.4 \% \\
(n=19)\end{array}$ & $\begin{array}{l}19.4 \% \\
(n=19)\end{array}$ & $\begin{array}{l}40.8 \% \\
(n=40)\end{array}$ & $\begin{array}{l}11.2 \% \\
(n=11)\end{array}$ \\
\hline \multicolumn{6}{|l|}{ Question 6} \\
\hline $\begin{array}{l}\text { My univ views } \\
\text { service as } \\
\text { scholarship }\end{array}$ & $\begin{array}{l}7.4 \% \\
(n=7)\end{array}$ & $\begin{array}{l}10.5 \% \\
(n=10)\end{array}$ & $\begin{array}{l}22.1 \% \\
(n=21)\end{array}$ & $\begin{array}{l}37.9 \% \\
(n=36)\end{array}$ & $\begin{array}{l}22.1 \% \\
(\mathrm{~N}=21)\end{array}$ \\
\hline \multicolumn{6}{|l|}{ Question 8} \\
\hline $\begin{array}{l}\text { Collaborative } \\
\text { faculty } \\
\text { scholarship is } \\
\text { valued by my } \\
\text { univ }\end{array}$ & $\begin{array}{c}17.2 \% \\
(n=17)\end{array}$ & $\begin{array}{c}39.4 \% \\
(n=39)\end{array}$ & $\begin{array}{l}29.3 \% \\
(n=29)\end{array}$ & $\begin{array}{l}8.1 \% \\
(n=8)\end{array}$ & $\begin{array}{l}6.1 \% \\
(n=6)\end{array}$ \\
\hline
\end{tabular}


Table 2. Student Mentorship and Its Products

\begin{tabular}{|c|c|c|c|c|c|}
\hline & $\begin{array}{l}\text { Strongly } \\
\text { Agree }\end{array}$ & Agree & Unsure & Disagree & $\begin{array}{l}\text { Strongly } \\
\text { Disagree }\end{array}$ \\
\hline $\begin{array}{l}\text { Question } 9 \\
\text { Student } \\
\text { mentorship } \\
\text { is valued by } \\
\text { my univ }\end{array}$ & $\begin{array}{l}20.6 \% \\
(n=20)\end{array}$ & $\begin{array}{l}41.2 \% \\
(n=40)\end{array}$ & $\begin{array}{l}21.6 \% \\
(n=21)\end{array}$ & $\begin{array}{l}11.3 \% \\
(n=11)\end{array}$ & $\begin{array}{l}5.2 \% \\
(n=5)\end{array}$ \\
\hline $\begin{array}{l}\text { Question } 10 \\
\text { Mentorship } \\
\text { is embedded } \\
\text { in all my } \\
\text { academic } \\
\text { activities }\end{array}$ & $\begin{array}{l}35.3 \% \\
(n=25)\end{array}$ & $\begin{array}{l}41.4 \% \\
(n=41)\end{array}$ & $\begin{array}{l}18.2 \% \\
(n=18)\end{array}$ & $\begin{array}{l}12.2 \% \\
(n=12)\end{array}$ & $\begin{array}{l}3.0 \% \\
(n=3)\end{array}$ \\
\hline $\begin{array}{l}\text { Question } 11 \\
\text { Student } \\
\text { mentorship } \\
\text { should be } \\
\text { included in } \\
\text { research for } \\
\text { new } \\
\text { knowledge }\end{array}$ & $\begin{array}{l}12.2 \% \\
(n=12)\end{array}$ & $\begin{array}{l}42.2 \% \\
(n=42)\end{array}$ & $\begin{array}{l}29.3 \% \\
(n=29)\end{array}$ & $\begin{array}{l}12.1 \% \\
(n=12)\end{array}$ & $\begin{array}{l}4.0 \% \\
(n=4)\end{array}$ \\
\hline
\end{tabular}

Table 2. (cont'd) Student Mentorship and Its Products

\begin{tabular}{|c|c|c|c|c|c|}
\hline & $\begin{array}{l}\text { Strongly } \\
\text { Agree }\end{array}$ & Agree & Unsure & Disagree & $\begin{array}{l}\text { Strongly } \\
\text { Disagree }\end{array}$ \\
\hline \multicolumn{6}{|l|}{ Question 12} \\
\hline $\begin{array}{l}\text { Mentoring } \\
\text { students in } \\
\text { research } \\
\text { provides } \\
\text { valuable } \\
\text { learning exp. }\end{array}$ & $\begin{array}{l}48.5 \% \\
(n=48)\end{array}$ & $\begin{array}{l}45.5 \% \\
(n=45)\end{array}$ & $\begin{array}{l}4.0 \% \\
(n=4)\end{array}$ & $\begin{array}{l}2.0 \% \\
(n=2)\end{array}$ & $\begin{array}{l}0 \% \\
(n=0)\end{array}$ \\
\hline \multicolumn{6}{|l|}{ Question 13} \\
\hline $\begin{array}{l}\text { Products from } \\
\text { student } \\
\text { mentored } \\
\text { projects should } \\
\text { serve solely as } \\
\text { student } \\
\text { scholarship }\end{array}$ & $\begin{array}{l}4.2 \% \\
(n=4)\end{array}$ & $\begin{array}{l}18.8 \% \\
(n=18)\end{array}$ & $\begin{array}{l}12.5 \% \\
(n=12)\end{array}$ & $\begin{array}{l}44.8 \% \\
(n=43)\end{array}$ & $\begin{array}{l}19.8 \% \\
(n=19)\end{array}$ \\
\hline \multicolumn{6}{|l|}{ Question 14} \\
\hline $\begin{array}{l}\text { Products from } \\
\text { student } \\
\text { mentored } \\
\text { projects can } \\
\text { serve as faculty } \\
\text { scholarship }\end{array}$ & $\begin{array}{l}23.2 \% \\
(n=23)\end{array}$ & $\begin{array}{l}44.4 \% \\
(n=44)\end{array}$ & $\begin{array}{l}13.1 \% \\
(n=13)\end{array}$ & $\begin{array}{l}14.1 \% \\
(n=14)\end{array}$ & $\begin{array}{l}5.1 \% \\
(n=5)\end{array}$ \\
\hline
\end{tabular}




\section{Table 3. Faculty Perceptions of Collaborative Products}

\begin{tabular}{|c|c|c|c|c|c|}
\hline & $\begin{array}{l}\text { Strongly } \\
\text { Agree }\end{array}$ & Agree & Unsure & Disagree & $\begin{array}{l}\text { Strongly } \\
\text { Disagree }\end{array}$ \\
\hline $\begin{array}{l}\text { Question } 15 \\
\text { Collaborative } \\
\text { scholarship } \\
\text { between } \\
\text { student and } \\
\text { faculty should } \\
\text { account for } \\
\text { contributions } \\
\text { for stu/fac }\end{array}$ & $\begin{array}{l}39.4 \% \\
(n=39)\end{array}$ & $\begin{array}{l}47.5 \% \\
(n=47)\end{array}$ & $\begin{array}{l}9.1 \% \\
(n=9)\end{array}$ & $\begin{array}{l}3.0 \% \\
(n=3)\end{array}$ & $\begin{array}{l}1.0 \% \\
(n=1)\end{array}$ \\
\hline $\begin{array}{l}\text { Question } 16 \\
\text { Student } \\
\text { research } \\
\text { products } \\
\text { require } \\
\text { fac/student } \\
\text { collaboration }\end{array}$ & $\begin{array}{l}28.6 \% \\
(n=28)\end{array}$ & $\begin{array}{l}32.7 \% \\
(n=32)\end{array}$ & $\begin{array}{l}17.3 \% \\
(n=17)\end{array}$ & $\begin{array}{l}20.4 \% \\
(n=20)\end{array}$ & $\begin{array}{l}1.0 \% \\
(n=1)\end{array}$ \\
\hline $\begin{array}{l}\text { Question } 17 \\
\text { Student } \\
\text { research } \\
\text { products } \\
\text { depend on } \\
\text { faculty } \\
\text { mentorship }\end{array}$ & $\begin{array}{l}27.3 \% \\
(n=27)\end{array}$ & $\begin{array}{l}41.4 \% \\
(n=41)\end{array}$ & $\begin{array}{l}22.2 \% \\
(n=22)\end{array}$ & $\begin{array}{l}8.1 \% \\
(n=8)\end{array}$ & $\begin{array}{l}1.0 \% \\
(n=1)\end{array}$ \\
\hline
\end{tabular}

\section{CONCLUSION}

While the data from this pilot study are from a small sample of faculty from one university, the findings do support the position that the work of a professor is the "scholarship of teaching" (Boyer, 1990). Clearly, a key part to the success of the doctoral student journey is the dynamic interplay between the mentor (scholar) and the mentee (student). This collaborative interplay fosters research productivity and positively impacts the production of new knowledge. Faculties in this study support the position that collaborative research products, which result in presentations and publications, serve a scholarship purpose for both the mentor and mentee. Along the doctoral journey, faculty can facilitate student development by employing student-centered mentorship strategies. Outcomes from this journey, which include research products, are thus collaborative efforts and should be counted as scholarship for all who contribute to their development.

\section{AUTHOR INFORMATION}

Dr. Pinto Zipp is Associate Professor and Chair of the Department of Graduate Programs in Health Sciences at Seton Hall University. She received her EdD from Teachers College Columbia University in 1996. She currently teaches management of neuromuscular problems in the Doctor of Physical Therapy program. Her research interests focus on, a) effects of performing dual tasks on walking performance and postural sway in children and adults, and b) curriculum design issues including the use of mind mapping and video based cases in professional education for the promotion of clinical decision making skills.

Dr. Cahill is an Associate Professor in the Department of Graduate Programs in Health Sciences at Seton Hall University. He received his EdD from the Executive Leadership Program of George Washington University in 2006. $\mathrm{He}$ teaches leadership and research courses in the $\mathrm{PhD}$ in Health Sciences program. HIs current research interests include the development of strategic thinking capability, executive sensemaking, plus, the influence of generational 
differences on the workplace. Dr. Cahill is a Fellow of the American College of Health Care Executives (ACHE) and the current ACHE Regent for N.J.

Dr. Clark is Professor of Health Sciences in the Department of Graduate Programs in Health Sciences at Seton Hall University. She received her EdD in Higher Education Administration and Management from University of Houston in 1983. Her current teaching responsibilities include scientific writing and research project design and methodology, as well as dissertation mentorship. Her current research interests include assessment of childhood obesity and higher education assessment and accreditation.

\section{REFERENCES}

1. Austin, A.E. \& Baldwin, RG. (1991). Faculty collaboration: Enhancing the quality of scholarship and teaching. ASHE-ERIC Higher Education Report No. 7.

2. Boyer, E.L. (1990). Scholarship reconsidered: Priorities of the professoriate. San Francisco: Jossey-Bass.

3. Forrest, S.P., \& Peterson, T.O. (2006). It's Called Andragogy. Academy of Management \& Education, 5(1): 119-121.

4. Pinto Zipp, G., \& Olson, V. (2008). Infusing the Mentorship Model of Education for the Promotion of Critical Thinking in Doctoral Education. Journal of College Teaching \& Learning, 5(9): 9-16. 


\section{NOTES}

